\title{
The importance of year-to-year variation in meteorological and runoff forcing for water quality of a temperate, dimictic lake
}

\author{
A. T. Romarheim ${ }^{1,{ }^{* *}}$, K. Tominaga ${ }^{2,3,{ }^{*}}$, G. Riise ${ }^{1}$, and T. Andersen ${ }^{2}$ \\ ${ }^{1}$ Department of Environmental Sciences, Norwegian University of Life Sciences, Ås, Norway \\ ${ }^{2}$ Department of Biosciences, University of Oslo, Oslo, Norway \\ ${ }^{3}$ Norwegian Institute for Water Research, Oslo, Norway \\ *now at: Centre for Ecological and Evolutionary Synthesis (CEES), Department of Biosciences, \\ University of Oslo, Oslo, Norway \\ *** deceased \\ Correspondence to: K. Tominaga (koji.tominaga@ibv.uio.no)
}

Received: 10 August 2014 - Published in Hydrol. Earth Syst. Sci. Discuss.: 10 November 2014 Revised: 21 April 2015 - Accepted: 27 April 2015 - Published: 8 June 2015

\begin{abstract}
Natural stochasticity can pose challenges in managing the quality of the environment, or hinder understanding of the system structure. It is problematic because unfavourable stochastic events cancel management efforts and because a favourable stochastic event may overestimate perceived success. This paper presents a variance-based modelling method that can be used to quantify the extent to which natural stochasticity can affect the target environment. We use a case study of a eutrophication assessment of a Norwegian lake, Årungen, using a lake model, MyLake, in order to present the method, and to investigate how this method could assist in answering scientific and management questions. Here we contrasted two effects of nutrient loading in runoff (partially controllable by policies) and meteorology (purely natural stochastic events), illustrated in the case study, in order to achieve the season-by-season quantification of mutually confounding factors of stochastic events. The results indicate that, for example, variation in runoff volume was most prevalent during autumn and winter, while variation in phosphorus inflow was most extensive from late winter to early spring. Thermal-related properties in the lake were well predicted by the model, and showed that the time of thermocline formation varied among years by more than 1 month, from mid-April to mid-May, whereas loading was the most important factor for phytoplankton biomass and water transparency. Mild winters and greater inputs of suspended matter and phosphorus were followed by increased phytoplankton biomass and light attenuation. These findings also
\end{abstract}

suggest that future changes in the global climate may have important implications for local water management decisionmaking. The present method of disentangling mutually confounding factors is not limited to lake water quality studies and may also provide utility in other types of aquatic system modelling.

\section{Introduction}

Natural stochasticity sometimes presents challenges in maintaining the quality of the environment. Such is the case in the context of reducing nutrient loads for the purpose of improving water quality of downstream environments (Deelstra et al., 2010; Skarbøvik and Bechmann, 2010). Natural variation in weather, for example, may confound costly abatement efforts by counteracting any positive benefits derived from the abatement itself. In particular, nutrient loading is determined both by hydrology (partially determined by meteorological forcing on land) and by the management effort (agriculture- and urban-related nutrient loading). Furthermore, the weather may be directly consequential in lake processes such as algal growth. With these challenges, it is paramount to evaluate to what extent confounding variables can actually make significant differences in lake water quality. The present study illustrates how a variance-based modelling method is able to disentangle two major factors affect- 
ing a lake, with a test case study of eutrophication recovery of a Norwegian lake.

The scientific community has learnt that nutrient enrichment of lakes may lead to high phytoplankton mass development, low water transparency, and fish mortality due to oxygen depletion (Smith et al., 1999). There are two main factors affecting the nutrient loading to lakes: (1) the soil and land use in the lake catchment, and (2) the hydrology of the watershed. Phosphorus is generally regarded as the limiting nutrient for phytoplankton production in freshwater lakes (Schindler, 1977). Much effort has therefore been given to reduce phosphorus input to aquatic ecosystems, which has demonstrably led to reduced phytoplankton production and increased water transparency in many lakes in Europe and North America (Jeppesen et al., 2005). On the other hand, many lakes have revealed delayed or negligible improvements in water quality despite reduced nutrient loading (Jeppesen et al., 2007a).

Year-to-year weather variations have also been recognized as affecting physical, chemical, and biological processes in lakes (Bailey-Watts and Kirika, 1999; Blenckner et al., 2007; Jeppesen et al., 2009, 2007b; Whitehead et al., 2009). An increase in air temperature has been shown to increase the water temperature (George et al., 2007) and the stability of thermal stratification (Straile et al., 2003a), change the phytoplankton community towards dominance of species adapted to warmer water (Weyhenmeyer et al., 2002), and possibly lead to earlier and higher phytoplankton production (Huber et al., 2008; Weyhenmeyer et al., 2002). Changes in thermal conditions and mixing regime can in turn influence the light, oxygen and nutrient dynamics in lakes, and thereby impact the phytoplankton primary production and community structure (Tirok and Gaedke, 2007; Wilhelm and Adrian, 2008). Precipitation is also deemed an important factor in determining water transparency, runoff intensity, and suspended matter discharge (Arheimer et al., 2005; Nõges et al., 2007; Ulén et al., 2007).

Norway has, generally, a low fraction of arable land (3\%) and low population density ( 12 persons $\mathrm{km}^{-2}$ ), so eutrophication is mainly recognizable in intensive agricultural districts at low altitudes. Lake Årungen is situated in a developed agricultural area in the south-east of Norway, and is one of the most nutrient-rich lakes in the country. Geological studies suggest that the natural phosphorus concentration of lakes in this area is $7-8 \mathrm{mg} \mathrm{m}^{-3}$ (Borch et al., 2007). Eutrophication became a problem in the lake during the 1960s, with phosphorus concentration exceeding $400 \mathrm{mg} \mathrm{m}^{-3}$ in the 1980s (Løvstad and Krogstad, 1993). Algal blooms, low water transparency, malodorous water, reduced fish stocks, and occasional mass mortality of fish were observed in the lake in this period (Ensby et al., 1984). Despite investments in sewage treatment and extensive changes in agricultural practices since the 1970s to reduce nutrient leaching and erosion from the catchment, algal growth remains high.
Predicting eutrophication responses to nutrient loading is a complex task due to the dynamics of a lake's response to the stochastic nature of weather, the confounding factor. Here we used a lake model, MyLake (Saloranta and Andersen, 2007), based on a system of processes that have been identified as a primary tool for improving our understanding of recovery and progression of eutrophication (Mooij et al., 2010). More precisely, we made combinations of forcing data (meteorological and nutrient loading inputs) for the model, with (1) some forcing data from the actual records and (2) others being the average day-to-day record for the period of 16 years, repeated 16 times.

This approach interweaves the day-to-day and year-toyear variability in a systematic manner, and simulation outputs based on dissimilar combinations of these "actual" and "repeated average year" can be analysed once again from the day-to-day and year-to-year variability. In principle, the actual data are more variable than the repeated average year. If a particular forcing variable is significant in affecting the lake water quality, switching from the actual to repeated average year reduces the year-to-year variation in lake water quality variables. More importantly, the current study demonstrates the use of year-to-year variance for each day of the year, which is a powerful visual and quantitative tool in detecting the critical season for a variable.

The separation of two temporarily varied factors affecting the same environmental receptor is not only useful in lake water quality modelling. For example, agricultural yield and forestry are affected by weather, soil conditions, diseases, and tilling and fertilization amount and timing. Other examples may be climate change impacts on the physical landscape, such as glacial extent or surface water ice cover, which are affected by stochastic meteorological conditions and warming forcing, which are mostly anthropogenic but also of natural origin (e.g. volcanic activities), as well as regional multi-year fluctuation such as the North Atlantic Oscillation or El Niño.

The current study primarily aims to evaluate the relative importance of year-to-year variation in two major factors, namely meteorological forcing and nutrient loading, which contribute to the lake's physical, chemical and biological conditions. We visually inspect how their respective significance varies over the season. To this aim, (1) the MyLake model was first calibrated against the lake data, then (2) various meteorological and nutrient loading scenarios combining variation in these two major factors were applied, and finally (3) year-to-year variation in model outputs was compared among the scenarios. 


\section{Material and methods}

\subsection{Study site}

Lake Årungen is a dimictic lake with maximum and average depths of 13 and $8 \mathrm{~m}$, respectively. The lake is located in south-east Norway $\left(59^{\circ} 41^{\prime} 18^{\prime \prime} \mathrm{N}, 10^{\circ} 44^{\prime} 38^{\prime \prime} \mathrm{E}\right.$; Fig. 1), $25 \mathrm{~km}$ south of Oslo, and has a surface area of $1.2 \mathrm{~km}^{2}$. The catchment area covers $51 \mathrm{~km}^{2}$, where $53 \%$ is agricultural land, $34 \%$ forestry, $10 \%$ densely populated, and $3 \%$ open water surfaces. The lake is highly exposed to agricultural runoff that causes high nutrient and particle loading. Runoff is mainly through six streams of 1.5 to $5 \mathrm{~km}$ length. The outlet connects the lake to the marine environment as Lake Årungen enters the Oslofjord through a $3 \mathrm{~km}$ long stream.

\subsection{Model}

MyLake is a one-dimensional lake model, adapted from MINLAKE (Riley and Stefan, 1988), which simulates daily changes in physical and chemical dynamics over the depth gradient (Saloranta and Andersen, 2007). The model simulates ice and snow dynamics in a mechanistic manner and it has been applied to winter-freezing lakes in Norway and Finland (Kankaala et al., 2006; Lydersen et al., 2003; Saloranta et al., 2009; Saloranta, 2006; Couture et al., 2014). It was therefore considered as a suitable model for Lake Årungen.

\subsection{Inputs and outputs}

MyLake requires inputs of meteorological forcing, runoff volume and temperature, and fluxes of suspended inorganic particles and total phosphorus (TP) to model phosphorus and phytoplankton dynamics in the lake (Table 1). Meteorological data for daily air temperature, global radiation, cloud cover, precipitation, relative humidity, and wind speed were obtained from the nearby meteorological station located at the Norwegian University of Life Sciences $\left(59^{\circ} 39^{\prime} 37^{\prime \prime} \mathrm{N}\right.$, $10^{\circ} 46^{\prime} 54^{\prime \prime} \mathrm{E}$ ). Direct measurements of daily runoff volume, runoff water temperature, and fluxes of suspended inorganic particles and total phosphorus to the study lake, Arungen, were not available. However these values were estimated using the Skuterud monitoring station (Fig. 1) with a hydrovolumetric weir at which these runoff variables were monitored (1994-2010), providing accurate flux at this sub-catchment. In order to account for runoff contributions of different types of land use in the other sub-catchments, such as agriculture and urban build-up, we used previously determined scaling factors that both correct for flow and nutrient contributors (Askilsrud, 2010). The monitoring station is located at an inlet stream to Østensjøvann $\left(59^{\circ} 41^{\prime} 18^{\prime \prime} \mathrm{N}, 10^{\circ} 49^{\prime} 45^{\prime \prime} \mathrm{E}\right)$, a small lake of $0.4 \mathrm{~km}^{2}$ which drains into Lake Årungen (Deelstra et al., 2007). A separate MyLake model was set up for Lake Østensjøvann to account for the buffering effects of this lake in the largest sub-catchment of Lake Årungen. The simulated water properties of Lake Østensjøvann were combined

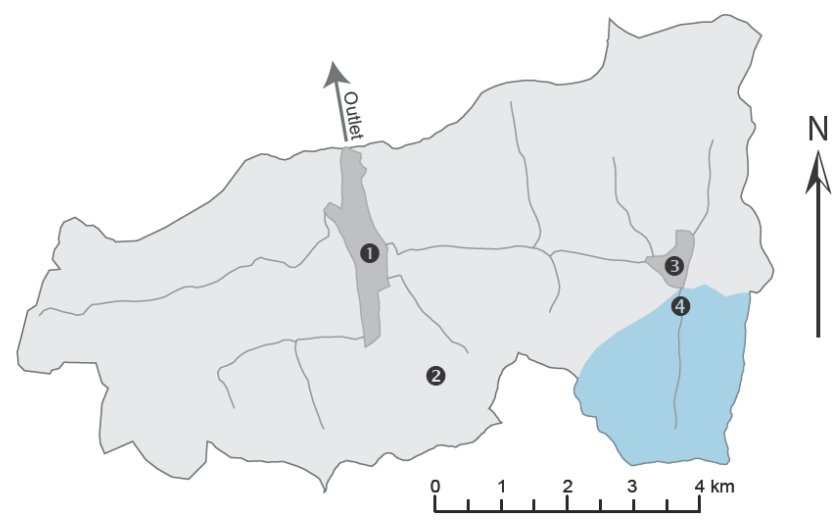

Figure 1. Map of catchment draining into (1) Lake Årungen, with the (2) weather station at Ås, (3) Lake Østensjøvannet and (4) the Skuterud monitoring station. Runoff data from the Skuterud subcatchment (indicated by dark shading) are scaled up according to land area and usage of the rest of the catchment to estimate the total loading to Lake Årungen.

with runoff from the other sub-catchments as an estimate of the total runoff to Lake Årungen.

Six variables (whole-lake average TP pool, mean surface chlorophyll concentration, light attenuation coefficient, thermocline depth, epilimnion temperature, and ice thickness) were calculated from unprocessed model outputs (Table 1) in order to ease interpretation of the statistical analyses for the scenario experiments described below.

\subsection{Model calibration}

Water temperature, TP, soluble reactive phosphorus (SRP), and chlorophyll $a$ concentration from the deepest location in the lake were used to calibrate the model (Table 1). Vertical water temperature profiles were continuously logged every hour at eight depths between 0.7 and $12.6 \mathrm{~m}$ by Hobo pendant temperature loggers (model 64K-UA-002-64; Onset Computer Corporation, Bourne, MA, USA) in the period from November 2008 to August 2010. Water samples for chemical and biological analyses were collected with a modified Ruttner water sampler at seven depths twice a month or monthly $(n=49)$ from January 2008 to September 2010. TP, SRP and chlorophyll $a$ were determined spectrophotometrically (UVVIS spectrophotometer UV-1201, Shimadzu, Kyoto, Japan).

We employed the Markov chain Monte Carlo (MCMC) method (Andrieu et al., 2003; Saloranta et al., 2009) during the calibration procedure. The calibration consisted of two stages. The first MCMC calibration stage involved three physical parameters (Table 2) that only affect heat dynamics, in particular thermocline depth. This first calibration was run against daily temperature measurements, using $2000 \mathrm{MCMC}$ steps with the first 1000 for burn-in. The second MCMC calibration stage involving eight parameters (Table 2) that affect phosphorus and chlorophyll dynamics, but not temperature, 
Table 1. Input and output data, and observed lake data for the calibration of the MyLake model and statistics for ANOVA and PCA.

\begin{tabular}{|c|c|c|}
\hline MyLake inputs & MyLake outputs (selected) & Observed lake data \\
\hline Meteorological data ${ }^{a, f}$ & Calibration purpose $e^{a}$ & Calibration purpose \\
\hline Air temperature & (every $0.5 \mathrm{~m}$ by depth) & (at 7 depths) \\
\hline Global radiation & Water temperature & Water temperature ${ }^{\mathrm{a}}$ \\
\hline Cloud cover & TP concentration & TP concentration ${ }^{b}$ \\
\hline Precipitation & SRP concentration & SRP concentration ${ }^{\mathrm{b}}$ \\
\hline Relative humidity & Chlorophyll concentration & Chlorophyll $a$ concentration ${ }^{b}$ \\
\hline \multicolumn{3}{|l|}{ Wind speed } \\
\hline & Statistics calculated for PCA & \\
\hline Runoff ${ }^{a, g}$ & (volume weighted mean $0-3.0 \mathrm{~m}$ ) & \\
\hline Flow volume & TP content & \\
\hline Water temperature & Mean surface chlorophyll & \\
\hline Suspended matter flux & Light attenuation coefficient & \\
\hline \multirow[t]{2}{*}{ TP flux } & Thermocline depth & \\
\hline & Mean epilimnion temperature ${ }^{\mathrm{e}}$ & \\
\hline Statistics calculated for PCA & Ice thickness & \\
\hline \multicolumn{3}{|l|}{ Global radiation ${ }^{\mathrm{c}}$} \\
\hline \multicolumn{3}{|l|}{ Cloud cover ${ }^{\mathrm{c}}$} \\
\hline \multicolumn{3}{|l|}{ Air temperature ${ }^{\mathrm{c}}$} \\
\hline \multicolumn{3}{|l|}{ Wind speed ${ }^{\mathrm{c}}$} \\
\hline \multicolumn{3}{|l|}{ Precipitation $^{\mathrm{c}}$} \\
\hline \multicolumn{3}{|l|}{ Flow volume ${ }^{\mathrm{c}}$} \\
\hline \multicolumn{3}{|l|}{ Winter air temperature ${ }^{\mathrm{d}, \mathrm{h}}$} \\
\hline \multicolumn{3}{|l|}{ Summer air temperature ${ }^{\mathrm{d}, \mathrm{i}}$} \\
\hline \multicolumn{3}{|l|}{ Winter precipitation ${ }^{\mathrm{d}, \mathrm{h}}$} \\
\hline \multicolumn{3}{|l|}{ Summer precipitation ${ }^{\mathrm{d}, \mathrm{i}}$} \\
\hline \multicolumn{3}{|l|}{ Suspended matter flux ${ }^{\mathrm{d}}$} \\
\hline TP flux ${ }^{\mathrm{d}}$ & & \\
\hline
\end{tabular}

was run against measurements of TP, SRP, and chlorophyll $a$ in 30000 MCMC steps with the first 10000 for burn-in. For example, algal growth in the MyLake model is a function of nutrient concentration, light availability and water temperature, and amplitude of these factors was controlled by the parameters. In the present study, runoff was given as external input to the model, and water temperature and underwater light conditions were determined in the first stage of MCMC. Therefore, for the example of algal growth, the second stage of MCMC only changed the amplitude of algal growth in response to these external factors. For these MCMC applications, convergence was monitored visually. Linear interpolation was used to match model outputs on a $0.5 \mathrm{~m}$ vertical grid to the actual measurement depths. Although it was not used directly during the MCMC calibration, model goodness of fit was informally assessed by root mean square error (RMSE). The medians of the posterior parameter distributions generated by both stages of the MCMC calibrations were used for the scenario experiments described in the following.

\subsection{The variance-based method for disentangling confounding factors}

The model was run under four scenarios for nutrient loading and weather in order to quantify the respective impacts of weather variation and loading conditions on phosphorus and phytoplankton dynamics (Table 3). Precipitation (in the meteorology group) predominantly influences runoff volume (in the runoff group). But runoff volume was kept together with runoff concentrations, as the most important influence possessed by runoff is the total amount of nutrients, which we obtain by multiplying concentration by volume. These scenarios were based on input combination of observed data (original data, 1994-2010) and synthetic data, where the synthetic data were created by taking the year-to-year mean ( $n=16$ ) of each of the days of year. Synthetic data repeat the calculated mean year with 365 days 16 times. We removed 29 February from the year-to-year mean calculation, and 28 February was repeated to account for the 29th day in leap years. 
Table 2. Parameters involved in calibration based on two-stage Markov chain Monte Carlo (MCMC) application (first stage for three parameters using 2000 MCMC steps with 1000 steps for burn-in and second stage for eight parameters using 30000 MCMC steps with 10000 for burn-in). MyLake equation numbers refer to the original model description (Saloranta and Andersen, 2007). Median values were chosen among the posterior parameter distribution.

\begin{tabular}{|c|c|c|c|c|}
\hline Parameter & Value & Equation & Unit & Prior distribution \\
\hline \multicolumn{5}{|c|}{ Physical parameters } \\
\hline Open-water vertical diffusion coefficient & $7.56 \times 10^{-3}$ & Eq. (10) & $\mathrm{m}^{2}$ day $^{-1}$ & $\begin{array}{l}0.00706 \times\left(1.18 \times\left(10^{x}\right) \times 10^{-6}\right)^{0.56} \\
\text { where } x \sim \mathrm{N}(0,1)\end{array}$ \\
\hline Wind sheltering coefficient & $7.96 \times 10^{-2}$ & Eq. (13) & - & $1-e^{-0.3 \times 1.18 \times 10^{x} \times 10^{-6}}$ where $x \sim \mathrm{N}(0,1)$ \\
\hline Minimum possible stability frequency & $9.31 \times 10^{-5}$ & Eq. (10) & $\mathrm{s}^{-2}$ & $1.14 \times 10^{-4} \times 10^{x}$ where $x \sim \mathrm{N}(0,1)$ \\
\hline \multicolumn{5}{|c|}{ Biological and chemical parameters } \\
\hline PAR saturation level for photosynthesis & $2.04 \times 10^{-4}$ & Eq. (29) & $\begin{array}{l}\text { mol quanta } \\
\mathrm{m}^{-2} \mathrm{~s}^{-1}\end{array}$ & $3.00 \times 10^{-5} \times 10^{x}$ where $x \sim \mathrm{N}(0,0.5)$ \\
\hline Particle resuspension mass transfer coefficient & $2.94 \times 10^{-5}$ & Sect. 2.7 & $\mathrm{~m}_{\text {day }}{ }^{-1}$, dry & $3.63 \times 10^{-7} \times 10^{x}$ where $x \sim \mathrm{N}(0,0.5)$ \\
\hline Settling velocity for suspended matter & 1.38 & Eq. (20) & $\mathrm{mday}^{-1}$ & $0.25 \times 10^{x}$ where $x \sim \mathrm{N}(0,0.5)$ \\
\hline Settling velocity for chlorophyll & $7.31 \times 10^{-2}$ & Eq. (20) & $\mathrm{m}$ day $^{-1}$ & $0.200 \times 10^{x}$ where $x \sim \mathrm{N}(0,0.5)$ \\
\hline Specific mortality rate of phytoplankton & $1.86 \times 10^{-1}$ & Eq. (26) & day $^{-1}$ & $0.200 \times 10^{x}$ where $x \sim \mathrm{N}(0,0.5)$ \\
\hline Max specific growth rate of phytoplankton & 1.76 & Eq. (27) & day $^{-1}$ & $1.50 \times 10^{x}$ where $x \sim \mathrm{N}(0,0.5)$ \\
\hline $\begin{array}{l}\text { Half-saturation inorganic phosphorus } \\
\text { concentration for Langmuir isotherm }\end{array}$ & $9.99 \times 10^{2}$ & Eq. (24) & $\mathrm{mg} \mathrm{m}^{-3}$ & $2500 \times 10^{x}$ where $x \sim \mathrm{N}(0,0.5)$ \\
\hline Saturation level for inorganic phosphorus isotherm & $4.96 \times 10^{4}$ & Eq. (24) & $\mathrm{mg} \mathrm{kg}^{-1}$ & $8000 \times 10^{x}$ where $x \sim \mathrm{N}(0,0.5)$ \\
\hline
\end{tabular}

This approach combines the actual forcing data for some variables together with average-year data for the other forcing data variables. Comparing such a synthetic scenario against the scenario using full actual forcing data elucidates the importance of year-to-year variation in the second set of variables. For example, scenario $\mathrm{C}$ (repeated average-year runoff) will necessarily have lower year-to-year variation $(n=16)$ in output variables compared with scenario A (full original data) (Table 3); the difference in the scenario input (i.e. runoff input) accounts for the reduction in the year-toyear variation in the output variables. By examining which output variables were most reduced in year-to-year variation among all output variables, we obtain crucial information on the importance of runoff forcing data in the output. Thus we achieved the objective of the present study, namely disentangling the relative importance of year-to-year variation in two major factors (meteorological and loading inputs). The idea of mixing actual and average-year forcing data was derived from the study conducted by Jöhnk et al. (2008), in which the authors assessed the relative importance of various meteorological variables (air temperature, cloudiness, wind speed) in affecting various lake responses such as water temperature and algal cell counts of three phytoplankton groups. The present study compares standard deviation of the 16 years of simulation outputs for each day of the year for six output variables among several scenarios.

Combining the repeated average input together with actual stochastic input (such as in scenarios B and C, Table 3) causes unrealistic input for two reasons. One reason is the inconsistency among variables on a daily basis. For exam-
Table 3. Model scenarios. The scenarios comprise either original input data (denoted $\mathrm{O}$ ), pseudo-repeated average year based on 16 years of input data (denoted $\mathrm{R}$ ), or a combination of $\mathrm{O}$ and $\mathrm{R}$.

\begin{tabular}{|c|c|c|c|c|}
\hline Model scenarios & A & B & $\mathrm{C}$ & $\mathrm{D}$ \\
\hline \multicolumn{5}{|l|}{ Model inputs } \\
\hline \multicolumn{5}{|c|}{ Weather } \\
\hline Global radiation & $\mathrm{O}$ & $\mathrm{R}$ & $\mathrm{O}$ & $\mathrm{R}$ \\
\hline Cloud cover & $\mathrm{O}$ & $\mathrm{R}$ & $\mathrm{O}$ & $\mathrm{R}$ \\
\hline Relative humidity & $\mathrm{O}$ & $\mathrm{R}$ & $\mathrm{O}$ & $\mathrm{R}$ \\
\hline Wind speed & $\mathrm{O}$ & $\mathrm{R}$ & $\mathrm{O}$ & $\mathrm{R}$ \\
\hline Air pressure & $\mathrm{O}$ & $\mathrm{R}$ & $\mathrm{O}$ & $\mathrm{R}$ \\
\hline Air temperature & $\mathrm{O}$ & $\mathrm{R}$ & $\mathrm{O}$ & $\mathrm{R}$ \\
\hline Precipitation & $\mathrm{O}$ & $\mathrm{R}$ & $\mathrm{O}$ & $\mathrm{R}$ \\
\hline \multicolumn{5}{|c|}{ Runoff } \\
\hline Flow volume & $\mathrm{O}$ & $\mathrm{O}$ & $\mathrm{R}$ & $\mathrm{R}$ \\
\hline Suspended matter flux & $\mathrm{O}$ & $\mathrm{O}$ & $\mathrm{R}$ & $\mathrm{R}$ \\
\hline Inflow water temperature & $\mathrm{O}$ & $\mathrm{O}$ & $\mathrm{R}$ & $\mathrm{R}$ \\
\hline TP flux & $\mathrm{O}$ & $\mathrm{O}$ & $\mathrm{R}$ & $\mathrm{R}$ \\
\hline
\end{tabular}

ple, because runoff is controlled by precipitation, scenario C, for instance (original weather + averaged runoff), may suffer from a potentially undesirable situation on a daily basis, such as high precipitation with little cloud on a certain day. However, day-to-day inconsistency, stemming from this unrealistic situation, has minimal influence on the lake ecosystem because (1) runoff and weather have different main roles: as a source of nutrients and a source of energy, respectively, and 
(2) because lake water is an accumulation of old water from runoff introduced many days before. The second reason for a lack of realism is that the intra-variability or within-year variability that naturally stochastic variables such as meteorological inputs should have is lost in the present study's design. This can cause problems such as not providing extreme wind events due to averaging, despite such wind events being crucial for the onset of ice formation, or determination of the thermocline. Hydrodynamic models are therefore usually driven by stochastically generated time series (Semenov et al., 1998; Schlabing et al., 2014). Alternatively, most average-looking years could have been chosen, as in Jöhnk et al. (2008). However, the current study requires the average to be done on multiple criteria or variables. By rendering a choice of one year as the average year for a certain variable, it will not necessarily be the average year for all variables concurrently. To achieve the purpose of reducing the year-to-year variation and not to be particularly bound by a selected single year or randomly generated year, repeated average year was used despite these potential problems. In the present study, year-to-year variation in outputs of these four scenarios will be discussed, but not the actual values on a daily basis, and the results are interpreted with care that scenario $\mathrm{A}$ is the most variable on a year-to-year basis, that either B or C is the next, and finally that D is the least, although this care does not completely safeguard the results from unrealistic intra-year variations or inconsistencies.

\subsection{Post-simulation methods}

All the data and statistical analyses were done using R (version 3.1.2, R Core Team, 2014). A two-way analysis of variance (ANOVA) was run on the 16 years of water-year-based simulation statistics (water year mean; see Table 1), among scenarios A, B, C and D (two weather factors by two loading factors; see Table 3). All annual averages are computed over the period from 1 October to 30 September, commonly used in Europe to refer to a hydrological year, or a water year (Otnes and Ræstad, 1978). Since treatment contrasts are nested within water years, we factored out the between-year variances to gain a greater power in the statistical tests. Principal component analysis (PCA) was used to explore the relationships between meteorological and land-related forcing and their relevance for the simulated lake response. Four water years with extreme PCA scores were selected for studying contrasting lake responses in closer detail.

\section{Results}

\subsection{Calibration}

The simulated water temperature and thermal dynamics of the lake were in agreement with the lake observed data. Observed water temperature measurements were well predicted by simulation and the RMSE was less than $2{ }^{\circ} \mathrm{C}$ at all lake depths (Fig. 2). After the water temperature calibration, parameters controlling TP, SRP, and chlorophyll $a$ were calibrated against observed data for the period from January 2008 to September 2010. The epilimnion TP, SRP, and chlorophyll $a$ concentrations were well predicted by the model, although their prediction was less successful than the prediction of the water temperature. The TP and SRP were better predicted by the model in pelagic surface water than in deep water, whereas the chlorophyll $a$ showed the opposite pattern. In general, the model simulated TP and SRP well, although both phosphorus forms were overestimated in early spring and autumn at shallow depths, while underestimated in bottom water. Simulated SRP concentrations were also somewhat higher than observed in winters. However, the simulation succeeded in showing a decreasing trend of lake phosphorus in spring and midsummer, and in mimicking its increase during the autumn mixing of water. Although the simulated chlorophyll concentrations were lower than the measured values, the model was able to predict seasonal variation in phytoplankton primary production and to simulate high phytoplankton biomasses in the lake epilimnion during midsummer.

\subsection{Variability in forcing data}

Inter-annual variation was expressed as the standard deviation in inputs and outputs between the years. All weather inputs varied between years (Fig. 3), with air temperature and global radiation having the strongest seasonal pattern in inter-annual variation (i.e. greater 16-year variation as compared to year-to-year variation on a day-of-year basis). The inter-annual variation in air temperature was strongest in the winter period, whereas global radiation varied most during the summer months. The variation in cloud cover, precipitation and relative humidity was generally similar across seasons. The year-to-year variation for precipitation was particularly high in December and in the period from July to September, the latter reflecting extreme precipitation events. Wind speed varied most in winters.

Runoff input data on water flow and concentrations of TP and suspended matter all varied seasonally and between years. The variation in runoff volume was greatest in the period from October to May. No clear seasonal pattern in the degree of variability could be found for suspended matter and TP fluxes, although the variation in TP influx seemed to peak in February and March.

\subsection{Variability in simulation outputs: disentangled significance of confounding factors}

Differences in year-to-year variation among the scenarios (Fig. 4) and the annual statistics (Table 4) illustrate the seasonal influence of the external forcing on the thermal regime and the phosphorus and phytoplankton dynamics in the lake. There is a large amount of $\mathrm{N}$ in Lake Arungen, as $\mathrm{N}$ is ap- 
Water temperature $\left({ }^{\circ} \mathrm{C}\right)$
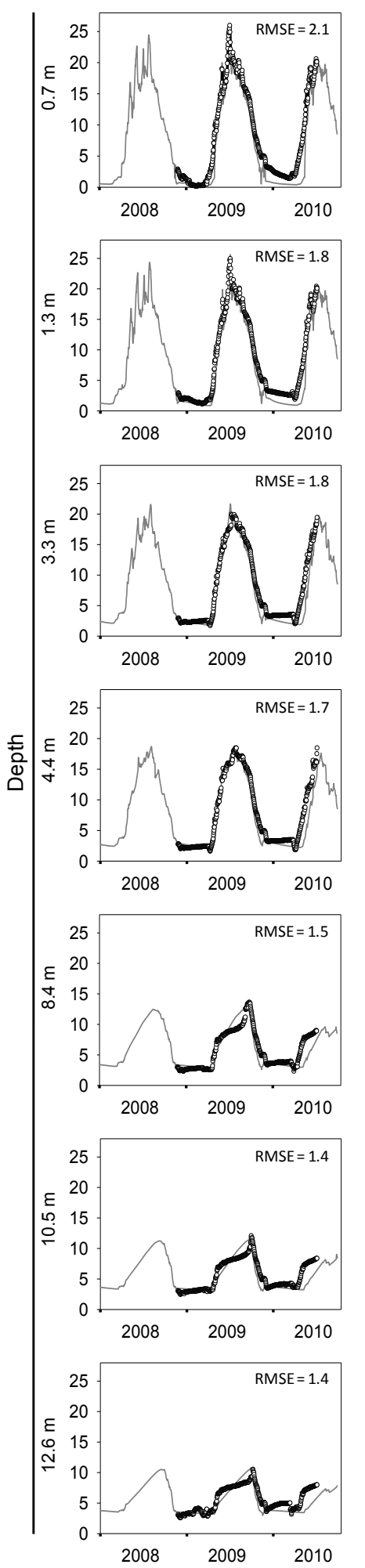

$\operatorname{TP}\left(\mathrm{mg} \mathrm{m}^{-3}\right)$
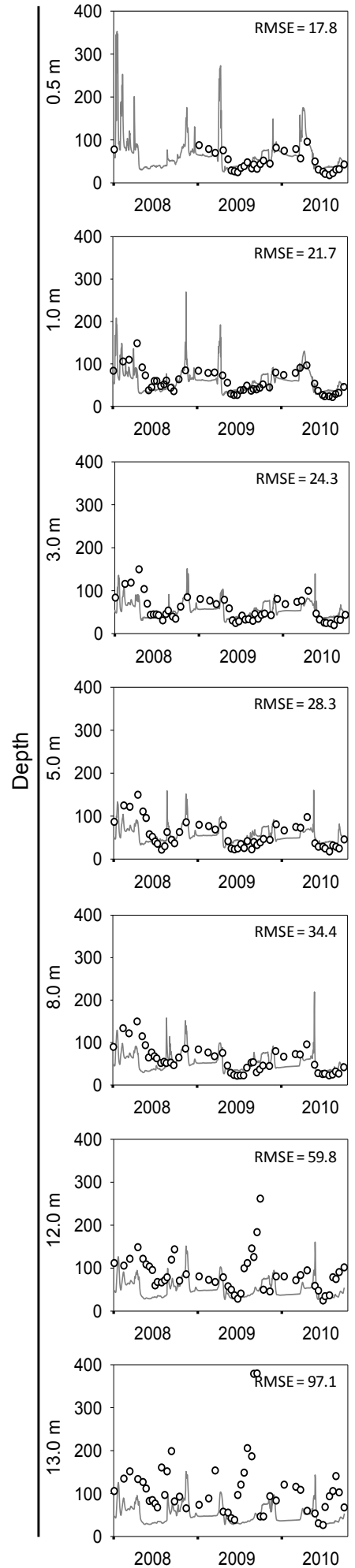

$\operatorname{SRP}\left(\mathrm{mg} \mathrm{m}^{-3}\right)$
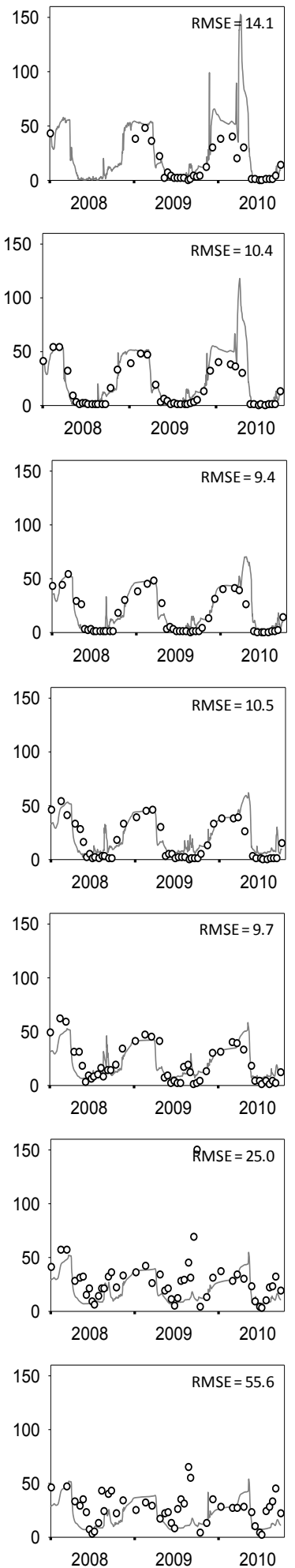

Chlorophyll $a\left(\mathrm{mg} \mathrm{m}^{-3}\right)$
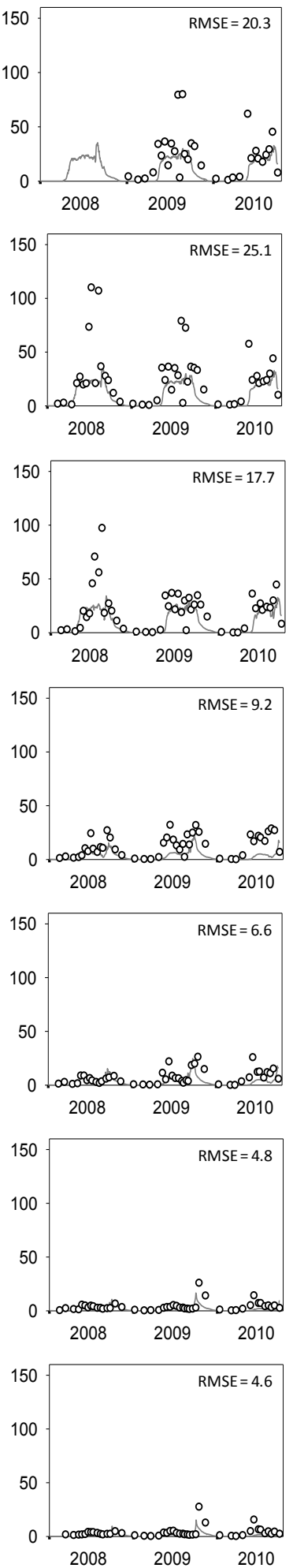

Figure 2. Simulated (line) and observed (circles) lake state variables for water temperature, TP, SRP, and chlorophyll $a$ concentrations at seven depths. RMSE values are in their respective original units, and they are shown only for presentation purposes and were not used during the calibration. See text for the details of the calibration procedure. 

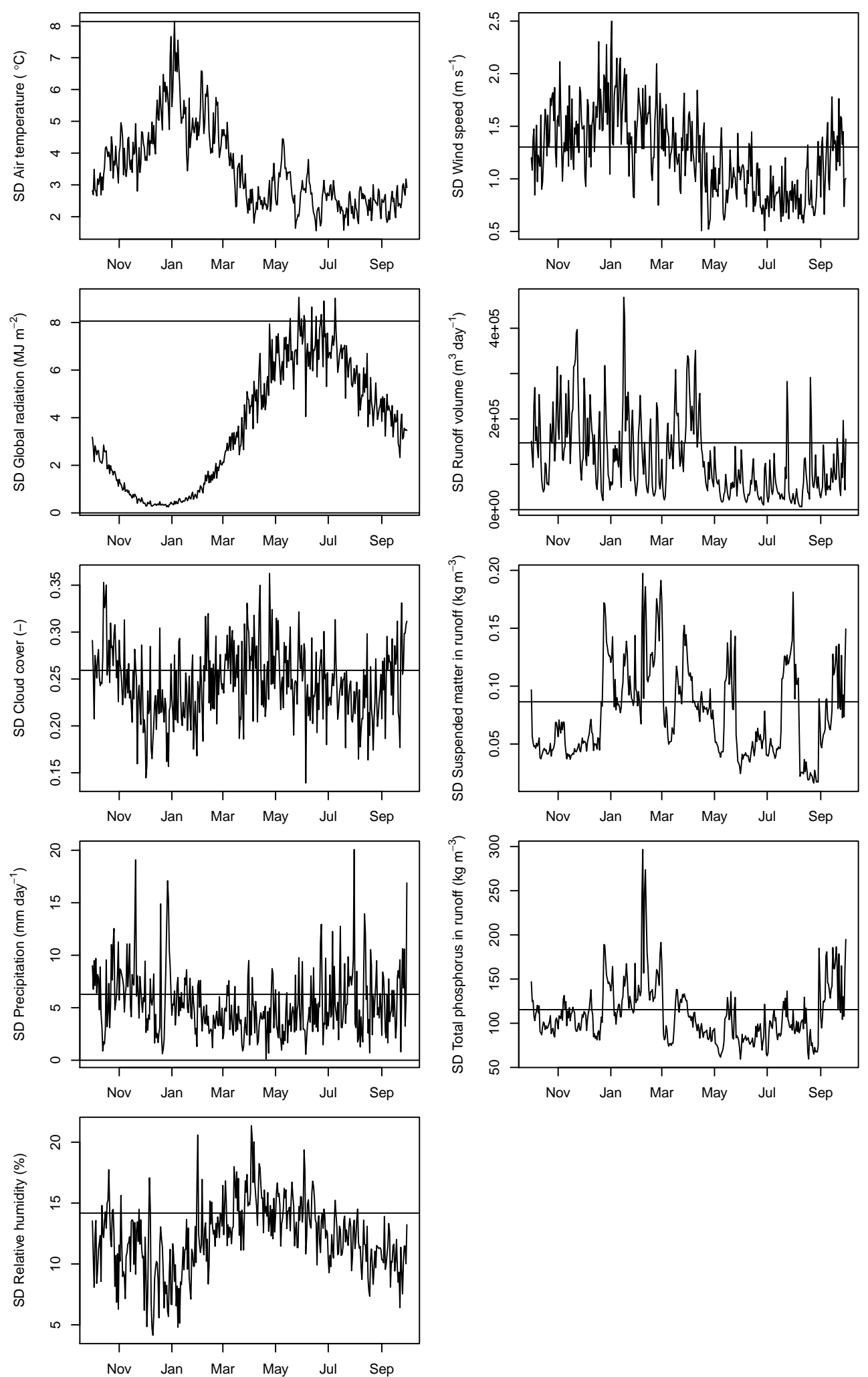

Figure 3. Input variability shown as standard deviations on a water year scale (day-by-day, year-to-year variation, $n=16$, curves), with the overall 16 year standard deviations indicated by horizontal lines. 
Table 4. Summary results for six two-factor within-subject ANOVAs $(n=16 \times 2 \times 2)$. Significance of additive and interactive effects of weather (two levels, original, $\mathrm{O}$ or repeated average, $\mathrm{R}$ ) and loading (two levels, original, $\mathrm{O}$ or repeated average, R) inputs on the six selected model outputs are shown using $P$ value. High $P$ values for interactive effects for all six tests indicate pure additive two-factor model and test for each factor separately. The variance decomposition shows the relative contributions of each factor and interaction to the total sum of squares with the between-year error term factored out.

\begin{tabular}{|c|c|c|c|c|c|c|c|c|c|}
\hline \multirow[b]{2}{*}{ Model outputs } & \multicolumn{3}{|c|}{$F$ value } & \multicolumn{3}{|c|}{$P$ value } & \multicolumn{3}{|c|}{ Variance decomposition } \\
\hline & $\mathrm{W}$ & $\mathrm{L}$ & $\mathrm{W} \times \mathrm{L}$ & $\mathrm{W}$ & $\mathrm{L}$ & $\mathrm{W} \times \mathrm{L}$ & $\mathrm{W}$ & $\mathrm{L}$ & $\mathrm{W} \times \mathrm{L}$ \\
\hline Ice thickness & 31.93 & 0.13 & 0.34 & $<0.000$ & 0.723 & 0.565 & 0.413 & 0.002 & 0.004 \\
\hline Thermocline depth & 0.27 & 0.91 & 1.93 & 0.605 & 0.346 & 0.172 & 0.006 & 0.019 & 0.040 \\
\hline Epilimnion temperature & 3.19 & 4.91 & 0.39 & 0.081 & 0.032 & 0.537 & 0.060 & 0.092 & 0.007 \\
\hline TP content & 0.81 & 1.26 & 0.02 & 0.374 & 0.268 & 0.888 & 0.017 & 0.027 & 0.000 \\
\hline Surface chlorophyll & 0.05 & 18.76 & 0.14 & 0.827 & $<0.000$ & 0.713 & 0.001 & 0.293 & 0.002 \\
\hline Light attenuation coefficient & 0.78 & 14.82 & 0.23 & 0.382 & $<0.000$ & 0.631 & 0.013 & 0.244 & 0.004 \\
\hline
\end{tabular}

plied in surplus in the agricultural fields. Even though there is some reduction in $\mathrm{N}$ during summer, $\mathrm{N}$ is excluded as the limiting nutrient (Romarheim, 2012). The lake responded differently between years; all simulated outputs, except ice thickness, showed large variation in the beginning and at the end of the phytoplankton growing season (Fig. 4). All simulated output variables were influenced by external forcing as they varied inter-annually for all model scenarios (see variance decomposition in Table 4). Ice thickness was significantly affected by weather $(P<0.001)$ as both air temperature and winter precipitation highly contributed to its variation between years (Table 4; Fig. 4). The variation in thermocline depth in May and October was well revealed by the model, and seemed to be equally dependent on weather and loading. The epilimnion temperature during the whole growing season was largely controlled by weather. The TP content in the lake was most variable in the period from November to January, and in April and July. Loading could mostly explain the inter-annual TP variation in the lake, whereas precipitation contributed to TP variation only in the spring, and air temperature only during the winter period. Loading was the overall most important factor in controlling the light attenuation coefficient $(P<0.001)$ and surface chlorophyll concentration $(P<0.001)$. Weather seemed to be important in controlling chlorophyll and light attenuation in early spring, whereas loading was the most important factor controlling the both variables from June to September. The year-to-year variation in these two variables from June to September in scenario $\mathrm{C}$ was higher than scenario $\mathrm{A}$, despite scenario $\mathrm{C}$ being less variable year-to-year than scenario $\mathrm{A}$ in loading. This might be because scenario $\mathrm{C}$ may distribute the autumn runoff events that are still significant after spreading over the years, and this might have caused the light-related variables to be unstable on a day-to-day scale.

The years 1996, 2000, 2006 and 2007 were the four most extreme years determined on the basis of PCA (Fig. 5). The year 1996 was characterized by relatively low average annual air temperature, a thin cloud cover and low precipita- tion, which resulted in low epilimnion water temperature, short-lasting thermocline, low runoff volume, and TP in the lake. The year 2007 represents an opposite to 1996 regarding weather characteristics, resulting in a model simulation with relatively high average annual air temperature and precipitation. Increased wind speed, decreased air temperature, and decreased precipitation coincided with increased ice thickness and global radiation, such as in 2003-2006, 2009, and 2010. These weather conditions resulted in lower suspended inorganic particles and TP in runoff which coincided with lower surface chlorophyll concentration and light attenuation. The year 2006 was identified to be extreme during this period, with a cold winter followed by a warm summer. In contrast, the year 2000 was characterized as a year with less global radiation, lower summer air temperature, and higher wind speed, but with higher winter temperature and precipitation. Such weather conditions pronounced higher TP and suspended particles in runoff compared with an average year, resulting in a high surface chlorophyll concentration and lower water transparency.

The methodological choice of using a repeating average year (see Sect. 2.5) may have reduced the impact of extreme weather events but probably caused little difference in the overall interpretation and conclusion. But the result that the daily year-to-year variation for either scenario $\mathrm{B}$ or $\mathrm{C}$ closely followed scenario A, depending on the modelled variable (TP content, surface chlorophyll, light attenuation coefficient for scenario B, and ice thickness, thermocline depth, and epilimnion temperature for scenario $\mathrm{C}$ ), provides confidence that the conclusions will not change due to the methodological limitation.

\section{Discussion}

\subsection{Year-to-year variability in lake responses}

Year-to-year weather variations, as well as the influence of catchment land use and hydrology, hinder our understand- 

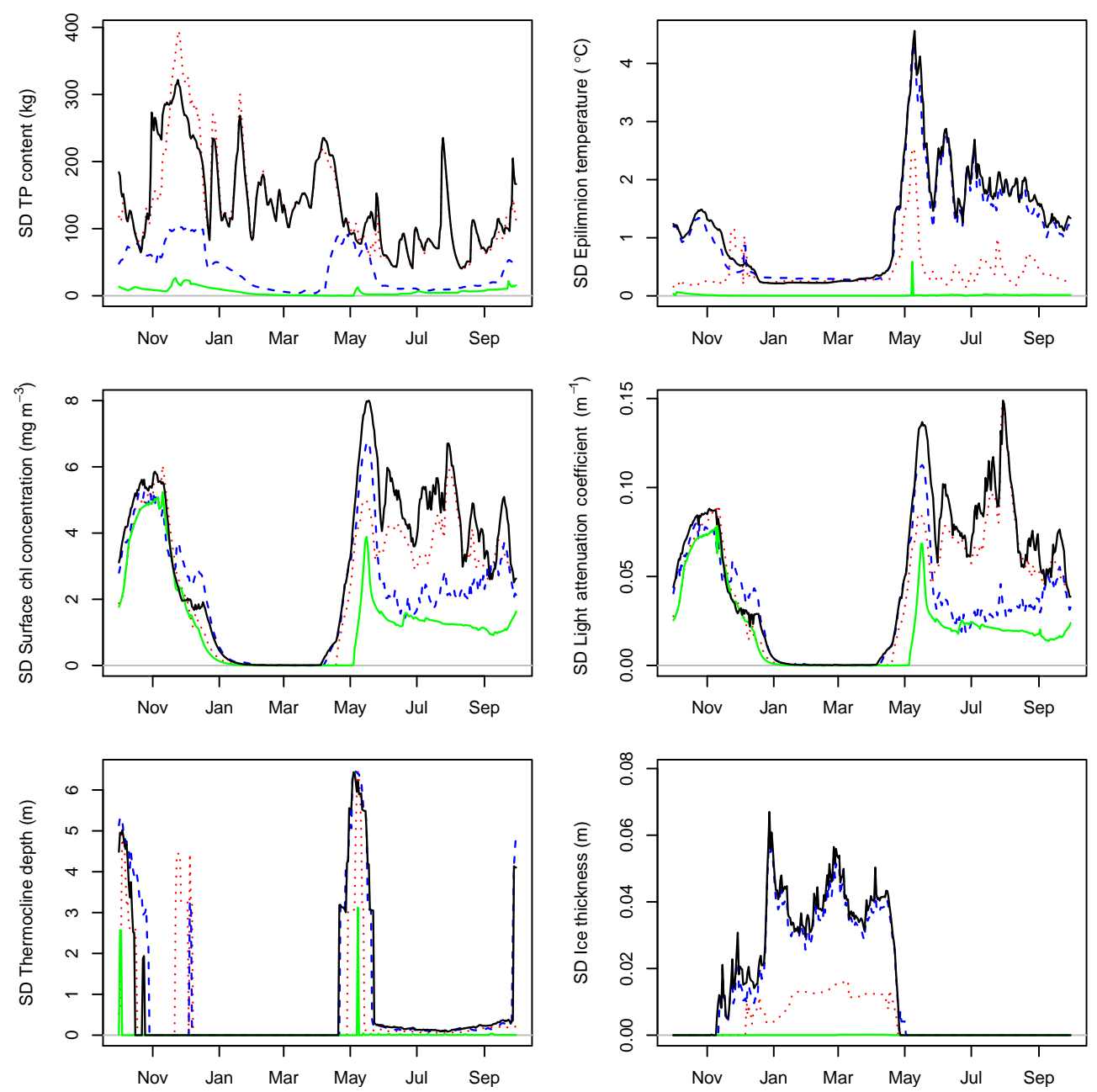

Figure 4. Output variability shown as standard deviations on a water year scale (day-by-day, year-to-year variation, $n=16$ ) for scenarios A (black solid line or top solid line), B (red dotted line), C (blue dashed line), and D (green solid line or bottom solid line). Consequently, each panel illustrates $4 \times 365$ standard deviation values, and each standard deviation is based on sample size $n=16$. See Table 3 for scenario configurations.

ing of how individual stressors may affect the lake response (Blenckner, 2005). Our model experiment, which involved the input of weather and loading data for 16 years, was able to outline the respective importance of year-to-year variation in external forcing on physical, chemical and biological response in Lake Arungen. The combination of high forcing variability and high lake response sensitivity made the interannual variation most dramatically expressed in spring and autumn.

Air temperature, precipitation, and wind speed are the principal factors influencing freshwater ecosystems in a changing climate (Nickus et al., 2010). The lake thermal regime was to a large extent affected by weather conditions, particularly by air temperature. The dynamics of winter air temperatures were an important factor influencing the heating and mixing processes during spring. A dynamic physical environment at the beginning of the growing season has con- siderable influence on the phytoplankton community structure and its dynamics (Weyhenmeyer et al., 2002). For example, increased surface water temperatures in the English Lake District (George et al., 2007) and incomplete water mixing in Lake Constance (Straile et al., 2003a) have previously been associated with mild winters. High inter-annual variation in winter air temperatures in Lake Årungen was reflected in the simulated ice thickness and phenology of ice formation, with ice forming in December-January and disappearing in March-April. Likewise, in other lake studies, thinner and shorter ice cover has been related to mild winters (Nickus et al., 2010). In this study, the timing of thermocline formation varied among years by more than 1 month, from mid-April to mid-May. The large year-to-year variation in thermocline depth and duration could lead to changes in temperature, light, and nutrient condition in the lake, which further shape the phytoplankton community and determine its 

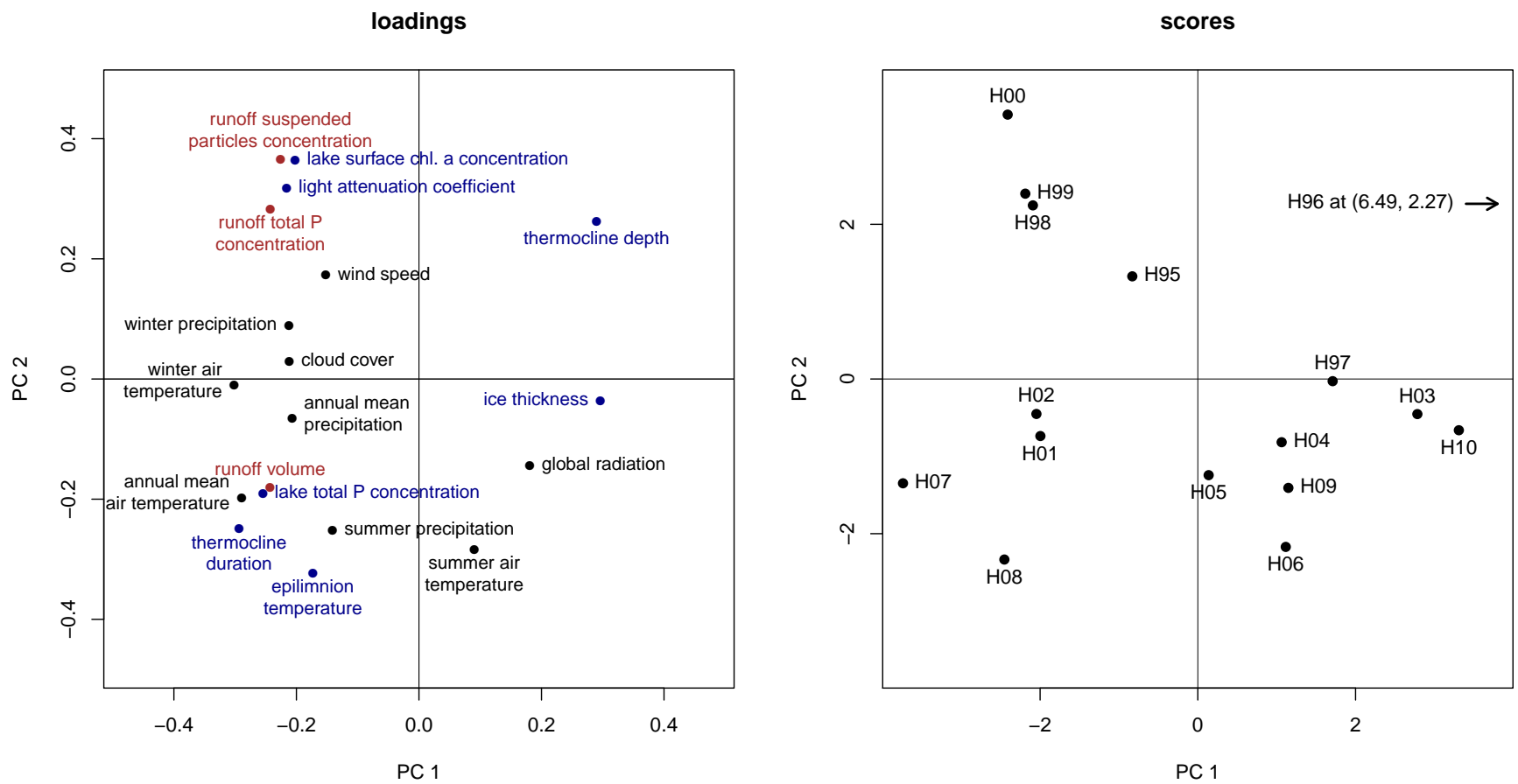

Figure 5. Principal component analysis (PCA) loadings for the two greatest components (explaining 39.0 and $16.5 \%$ of variance) and scores for the two components for 16 water years (letters). Black coding for PC loading indicates the weather input, brown the runoff input, and blue the lake simulation.

total biomass (Padisák et al., 2010; Zohary et al., 2010). For instance, the early disappearance of diatoms and high development of cyanobacteria in European lakes have been related to winter warming and increased water temperature (Weyhenmeyer et al., 2002). Furthermore, an increase in water stability favours the buoyant phytoplankton species such as bloom-forming cyanobacteria (Reynolds et al., 1983; Winder and Hunter, 2008).

Year-to-year variation in phosphorus content in the lake was highly influenced by nutrient loading. This indicates that the external nutrient supply remains an important source of phosphorus in the lake. Although changes in nutrient loading have been primarily linked to anthropogenic activities in the catchment, in particular to practices in agriculture, the short-term variations in weather and runoff can also influence the nutrient supply from external sources. Lake Årungen is surrounded by agricultural land, and is especially sensitive to variable weather conditions that promote nutrient loading from the catchment. More precisely, air temperature and rainfall frequency and intensity affect the runoff and the soil erosion pattern, particularly during the winter period. Increases in winter temperatures simultaneously occurring with frequent freezing and melting events increase the risk of erosion, which in turn increases the nutrient loading to the lake (Bechmann et al., 2005; Jeppesen et al., 2009; Nõges et al., 2007). Although not statistically demonstrated in the present study, the indirect impacts of weather conditions on discharge may still be important in regulating the nutrient dynamics. Variable winter weather conditions and the timing of ice-out were the most important causes of year-to-year variable phosphorus content in the period from November to January and in April in Lake Årungen. Enhanced phosphorus concentrations in streams during winter, and high phosphorus loading in early spring, both contribute to the total lake phosphorus concentration during the following summer in two Norwegian lakes with agricultural catchments (Bechmann et al., 2005). In addition, the variation in summer TP content could also be the result of between-year variation in rainfall, especially due to extreme precipitation events as observed for particular days in July. High inter-annual variation in TP content can consequently result in variable phytoplankton biomass between years.

Phytoplankton biomass and light were significantly affected by loading, although atmospheric forcing also contributed to their inter-annual variation in the lake. The effect of loading was pronounced during the whole algal growing season, whereas weather had the strongest effect in early spring and from mid-August to the end of the growing season. Thermal stratification is highly dependent on weather and may further influence water mixing as well as light and nutrient regimes, which are important in controlling phytoplankton dynamics (Padisák et al., 2010; Zohary et al., 2010). Similar patterns of year-to-year variation in water temperature, chlorophyll concentration, and light attenuation indicate a close relationship between these variables. Higher air temperature promoted higher water 
temperature and higher stability of the thermal stratification, which enhanced phytoplankton production of bloomforming cyanobacteria (Reynolds et al., 1983; Weyhenmeyer et al., 2002). Runoff and soil erosion, caused by intense precipitation and frequent melting of snow and ice during mild winters, affect eutrophication and water turbidity (Bechmann et al., 2005; Jeppesen et al., 2009). Thus, light may limit phytoplankton growth more than nutrients in highly turbid lakes such as Lake Årungen (Dokulil, 1994). Reduced light availability may be crucial for the competitive success of cyanobacteria which are functionally adapted to low-light conditions (Litchman, 1998). Particularly high dominance of cyanobacteria has been observed in Lake Årungen after mild winters followed by low-light conditions in spring (Romarheim et al., unpublished data). Therefore, additional measures to control soil erosion may need to be implemented in water management, not only to reduce the supply of nutrients but also to avoid low water transparency, which may favour development of potentially toxic cyanobacteria.

\subsection{Implications for lake management}

According to our PCA, most of the 1990s was categorized by winters with higher temperatures and more rainfall. The mild winters were related to a positive North Atlantic Oscillation (NAO) phase which has been shown to strongly influence physico-chemical and biological responses in western European lakes (George et al., 2007; Straile et al., 2003b; Weyhenmeyer et al., 2002). The effect of climate condition on water ecosystems, however, should be considered individually as the lake response is also determined by the lake's geographical position, landscape topography, and the lake's morphometry and mixing regime (Nickus et al., 2010). Our model experiment indicated that greater inflow of suspended matter and phosphorus to Lake Arungen is expected after mild winters with high precipitation. Consequently, higher chlorophyll concentrations and greater light attenuation were predicted after mild and wet winters such as in the year of 2000. Mild winters potentially counteract measures aimed to reduce external nutrient supply and control phytoplankton production in cold temperate lakes. However, cold winters were associated with a thicker ice layer, less inflow of suspended matter and phosphorus, and low chlorophyll and light attenuation. This was consistent with the observed increase in water transparency and reduction of phytoplankton biomass, particularly of cyanobacteria, in Lake Årungen after the cold winter of 2010 (Romarheim et al., unpublished data). Special attention must therefore be given to management practices, which should minimize the use of fertilizers and reduce the risk of nutrient runoff and soil erosion, especially in areas that drain directly into the lake. Higher annual air temperature coincided with a warmer epilimnion, a shallower thermocline, and extended summer stratification, such as for the year 2007. In addition, high annual precipitation and runoff volume, particularly in summer, coincided with warmer years.

Globally, all years in the period from 1995 to 2006, with the exception of 1996, were among the warmest since 1850 (Trenberth et al., 2007). Likewise, the year 1996 was characterized by low average annual air temperature in our model experiment. Lower annual air temperature and low rainfall in 1996 led to low epilimnion temperature, and a deep and short-lasting thermocline. According to future climate projections for Scandinavia, warmer and wetter winters are expected in south-eastern Norway (Hanssen-Bauer et al., 2005). If so, we should also expect more intensive soil erosion, higher phosphorus loading, lower water transparency, and greater phytoplankton biomasses, primarily cyanobacteria, in the lakes. Global climate changes and inter-annual variations in the local weather directly, and indirectly through an impact on the catchment, influence the physico-chemical and biological processes in lakes. The limnological and biogeochemical knowledge of this lake identified by decomposing year-to-year variation in the two factors has potential in determining future management. Runoff is partially controlled by precipitation, which in turn is predicted to change, and so are air temperature and global radiation. Therefore, the effects of climate should be critically considered in future decision-making processes concerning water management.

Acknowledgements. We thank the Norwegian Institute for Agricultural and Environmental Research (Bioforsk) for providing runoff data from Skuterud monitoring station. We also thank Johnny Kristiansen at the Department of Environmental Sciences, Norwegian University of Life Sciences for excellent assistance during the field and laboratory work. PURA, an EU water framework directive project within the Follo, Oslo region, Norway, is also thanked for financial support during the study. This work was partly carried out with support from the Research Council of Norway (Project Eutropia 190028/S30). We thank Tuomo Saloranta for providing an example code for parameter estimation. The calculations presented in this paper were made possible with freely available software, in particular Octave and R, and we are grateful for efforts made by the authors of the free software. This open-access publication was made possible with the Open Access Publication Fund at the University of Oslo.

Edited by: M. Hipsey

\section{References}

Andrieu, C., de Freitas, N., Doucet, A., and Jordan, M.: An introduction to MCMC for machine learning, Mach. Learn., 50, 5-43, 2003.

Arheimer, B., Andréasson, J., Fogelberg, S., Johnsson, H., Pers, C. B., and Persson, K.: Climate change impact on water quality: model results from southern Sweden, Ambio, 34, 559566, 2005. 
Askilsrud, H.: Nutrient Input to Lake Årungen: Assessment of Data Availability to Run the MyLake Model, MS Thesis, Norwegian University of Life Sciences, Ås, Norway, 2010.

Bailey-Watts, A. E. and Kirika, A.: Poor water quality in Loch Leven (Scotland) in 1995 in spite of reduced phosphorus loadings since 1985: the influences of catchment management and inter-annual weather variation, Hydrobiologia, 403, 135-151, doi:10.1023/A:1003758713050, 1999.

Bechmann, M., Berge, D., Eggestad, H., and Vandsemb, S.: Phosphorus transfer from agricultural areas and its impact on the eutrophication of lakes - two long-term integrated studies from Norway, J. Hydrol., 304, 238-250, 2005.

Blenckner, T.: A conceptual model of climate-related effects on lake ecosystems, Hydrobiologia, 533, 1-14, doi:10.1007/s10750004-1463-4, 2005.

Blenckner, T., Adrian, R., Livingstone, D. M., Jennings, E., Weyhenmeyer, G. A., George, D. G., Jankowski, T., Järvinen, M., Aonghusa, C. N., Nõges, T., Straile, D., and Teubner, K.: Large-scale climatic signatures in lakes across Europe: a meta-analysis, Global Change Biol., 13, 1314-1326, doi:10.1111/j.1365-2486.2007.01364.x, 2007.

Borch, H., Yri, A., Løvstad, Ø., and Turtumøygard, S.: Titaksplan for Årungen (Abatement measures for Lake Årungen, in Norwegian), Tech. Rep. 52, Norwegian Institute for Agricultural and Environmental Research, Ås, Norway, 2007.

Couture, R.-M., Tominaga, K., Starrfelt, J., Moe, S. J., Kaste, $\varnothing$., and Wright, R. F.: Modelling phosphorus loading and algal blooms in a Nordic agricultural catchment-lake system under changing land-use and climate, Environ. Sci. Proces. Imp., 16, 1588-1599, doi:10.1039/c3em00630a, 2014.

Deelstra, J., Ludvigsen, G. H., Pengerud, A., Eggestad, H. O., Tveiti, G., and Øygarden, L.: Jord- og vannovervåking i landbruket (JOVA): Skuterudbekken (Monitoring of soil and water in agriculture at Skuterud Stream, in Norwegian), Tech. Rep. 118, Norwegian Institute for Agricultural and Environmental Research, Ås, Norway, 2007.

Deelstra, J., Eggestad, H. O., Iital, A., Jansons, V., and Barkved, L. J.: Hydrology of small agricultural catchments in Norway, Latvia and Estonia. Vann, 3, 321-331, 2010.

Dokulil, M. T.: Environmental control of phytoplankton productivity in turbulent turbid systems, Hydrobiologia, 289, 65-72, doi:10.1007/BF00007409, 1994.

Ensby, S., Borgstrøm, R., Langeland, G., Rosland, F., and Sanni, S.: Årungen: tilstand, aktuelle sanerings- og restaureringstiltak: rapport utarbeidet på grunnlag av tverrfaglig forskningsaktivitet i perioden 1980-1983 (State, remediation and restoration measures in Lake Årungen: report based on interdisciplinary research in 1980-1983, in Norwegian), Institutt for Georessurs- og Forurensningsforskring, Ås, Norway, 1984.

George, G., Hurley, M., and Hewitt, D.: The impact of climate change on the physical characteristics of the larger lakes in the English Lake District, Freshwater Biol., 52, 1647-1666, doi:10.1111/j.1365-2427.2007.01773.x, 2007.

Hanssen-Bauer, I., Achberger, C., Benestad, R. E., Chen, D., and Forland, E. J.: Statistical downscaling of climate scenarios over Scandinavia, Clim. Res., 29, 255-268, doi:10.3354/cr029255, 2005 .
Huber, V., Adrian, R., and Gerten, D.: Phytoplankton response to climate warming modified by trophic state, Limnol. Oceanogr., 53, 1-13, doi:10.4319/1o.2008.53.1.0001, 2008.

Jeppesen, E., Søndergaard, M., Jensen, J. P., Havens, K. E., Anneville, O., Carvalho, L., Coveney, M. F., Deneke, R., Dokulil, M. T., Foy, B., Gerdeaux, D., Hampton, S. E., Hilt, S., Kangur, K., Köhler, J., Lammens, E. H., Lauridsen, T. L., Manca, M., Miracle, M. R., Moss, B., Nõges, P., Persson, G., Phillips, G., Portielje, R., Romo, S., Schelske, C. L., Straile, D., Tatrai, I., Willén, E., and Winder, M.: Lake responses to reduced nutrient loading - an analysis of contemporary long-term data from 35 case studies, Freshwater Biol., 50, 1747-1771, doi:10.1111/j.1365-2427.2005.01415.x, 2005.

Jeppesen, E., Meerhoff, M., Jacobsen, B. A., Hansen, R. S., Søndergaard, M., Jensen, J. P., Lauridsen, T. L., Mazzeo, N., and Branco, C. W. C.: Restoration of shallow lakes by nutrient control and biomanipulation - the successful strategy varies with lake size and climate, Hydrobiologia, 581, 269-285, doi:10.1007/s10750-006-0507-3, 2007a.

Jeppesen, E., Søndergaard, M., Meerhoff, M., Lauridsen, T. L., and Jensen, J. P.: Shallow lake restoration by nutrient loading reduction - some recent findings and challenges ahead, in: Shallow Lakes in a Changing World, edited by: Gulati, R. D., Lammens, E., Pauw, N. D., and Donk, E. V., Developments in Hydrobiology, no. 196, Springer Netherlands, Dordrecht, the Netherlands, 239-252, 2007b.

Jeppesen, E., Kronvang, B., Meerhoff, M., Sondergaard, M., Hansen, K. M., Andersen, H. E., Lauridsen, T. L., Liboriussen, L., Beklioglu, M., Ozen, A., and Olesen, J. E.: Climate change effects on runoff, catchment phosphorus loading and lake ecological state, and potential adaptations, J. Environ. Qual., 38, 1930-1941, 2009.

Jöhnk, K. D., Huisman, J., Sharples, J., Sommeijer, B., Visser, P. M., and Stroom, J. M.: Summer heatwaves promote blooms of harmful cyanobacteria, Global Change Biol., 14, 495-512, doi:10.1111/j.1365-2486.2007.01510.x, 2008.

Kankaala, P., Huotari, J., Peltomaa, E., Saloranta, T., and Ojala, A.: Methanotrophic activity in relation to methane efflux and total heterotrophic bacterial production in a stratified, humic, boreal lake, Limnol. Oceanogr., 51, 1195-1204, doi:10.4319/lo.2006.51.2.1195, 2006.

Litchman, E.: Population and community responses of phytoplankton to fluctuating light, Oecologia, 117, 247-257, doi:10.1007/s004420050655, 1998.

Løvstad, Ø. and Krogstad, T.: Årungen 1992: eutrofiering, plantenæringsstoffer og blågrønnalger (Lake Årungen 1992: eutrophication, plant nutrients and blue-green algae, in Norwegian), Institutt for Jordfag, Norges Landbrukshøgskole, Ås, Norway, 1993.

Lydersen, E., Aanes, K. J., Andersen, S., Andersen, T., Brettum, P., Bækken, T., Lien, L., Lindstrøm, E. A., Løvik, J. E., Mjelde, M., Oredalen, T. J., Lyche, A. S., Ropmstad, R., Rørslett, B., and Saloranta, T.: THERMOS-projektet: Fagrapport 1998-2002 (THERMOS Project technical report 1998-2002, in Norwegian), Tech. Rep. 4720, Norwegian Institute for Water Research, Oslo, Norway, 2003.

Mooij, W. M., Trolle, D., Jeppesen, E., Arhonditsis, G., Belolipetsky, P. V., Chitamwebwa, D. B. R., Degermendzhy, A. G., DeAngelis, D. L., Domis, L. N. D. S., Downing, A. S., Elliott, J. A., 
Fragoso, C. R., Gaedke, U., Genova, S. N., Gulati, R. D., Hakanson, L., Hamilton, D. P., Hipsey, M. R., 't Hoen, J., Huelsmann, S., Los, F. H., Makler-Pick, V., Petzoldt, T., Prokopkin, I. G., Rinke, K., Schep, S. A., Tominaga, K., Van Dam, A. A., Van Nes, E. H., Wells, S. A., and Janse, J. H.: Challenges and opportunities for integrating lake ecosystem modelling approaches, Aquat. Ecol., 44, 633-667, doi:10.1007/s10452-0109339-3, 2010.

Nickus, U., Bishop, K., Erlandsson, M., Evans, C. D., Forsius, M., Laudon, H., Livingstone, D. M., Monteith, D., and Thies, H.: Direct impacts of climate change on freshwater ecosystems, in: Climate Change Impacts on Freshwater Ecosystems, edited by: Kernan, R., Battarbee, R. W., and Moss, B., Wiley-Blackwell, Chichester, West Sussex, UK, 38-64, 2010.

Nõges, P., Kägu, M., and Nõges, T.: Role of climate and agricultural practice in determining matter discharge into large, shallow Lake Võrtsjärv, Estonia, in: Eutrophication of Shallow Lakes with Special Reference to Lake Taihu, China, edited by: Qin, B., Liu, Z., and Havens, K., Developments in Hydrobiology, no. 194, Springer Netherlands, Dordrecht, the Netherlands, 125-134, 2007.

Otnes, J. and Ræstad, E.: Hydrologi i praksis, Ingeniørforlaget, Oslo, Norway, 1978.

Padisák, J., Hajnal, É., Naselli-Flores, L., Dokulil, M. T., Nõges, P., and Zohary, T.: Convergence and divergence in organization of phytoplankton communities under various regimes of physical and biological control, Hydrobiologia, 639, 205-220, doi:10.1007/s10750-009-0021-5, 2010.

R Core Team: R: A language and environment for statistical computing, R Foundation for Statistical Computing, Vienna, Austria, 2014.

Reynolds, C. S., Wiseman, S. W., Godfrey, B. M., and Butterwick, C.: Some effects of artificial mixing on the dynamics of phytoplankton populations in large limnetic enclosures, J. Plankton Res., 5, 203-234, doi:10.1093/plankt/5.2.203, 1983.

Riley, M. J. and Stefan, H. G.: MINLAKE: a dynamic lake water quality simulation model, Ecol. Model., 43, 155-182, doi:10.1016/0304-3800(88)90002-6, 1988.

Romarheim, A. T.: Disentangling the effect of physical and chemical factors on phytoplankton dynamics in a highly eutrophic and turbid lake, PhD thesis, Norwegian University of Life Sciences, Ås, Norway, 2012.

Saloranta, T. M.: Highlighting the model code selection and application process in policy-relevant water quality modelling, Ecol. Model., 194, 316-327, doi:10.1016/j.ecolmodel.2005.10.031, 2006.

Saloranta, T. M. and Andersen, T.: MyLake - a multi-year lake simulation model code suitable for uncertainty and sensitivity analysis simulations, Ecol. Model., 207, 45-60, 2007.

Saloranta, T. M., Forsius, M., Jarvinen, M., and Arvola, L.: Impacts of projected climate change on the thermodynamics of a shallow and a deep lake in Finland: model simulations and Bayesian uncertainty analysis, Hydrol. Res., 40, 234-248, 2009.

Schindler, D. W.: Evolution of phosphorus limitation in lakes, Science, 195, 260-262, 1977.

Schlabing, D., Frassl, M. A., Eder, M. M., Rinke, K., and Bárdossy, A.: Use of a weather generator for simulating climate change effects on ecosystems: A case study on Lake Constance, Environ. Model. Softw., 61, 326-338. doi:10.1016/j.envsoft.2014.06.028, 2014.

Semenov, M.; Brooks, R.; Barrow, E., and Richardson, C.: Comparison of the WGEN and LARS-WG stochastic weather generators for diverse climates, Clim. Res., 10, 95-107, 1998.

Skarbøvik, E. and Bechmann, M.: Some characteristics of the Vansjø-Hobøl (Morsa) Catchment, Bioforsk Report 128, vol. 5, Bioforsk Soil and Environment, Ås, Norway, 2010.

Smith, V., Tilman, G., and Nekola, J.: Eutrophication: impacts of excess nutrient inputs on freshwater, marine, and terrestrial ecosystems, Environ. Pollut., 100, 179-196, 1999.

Straile, D., Jöhnk, K., and Rossknecht, H.: Complex effects of winter warming on the physicochemical characteristics of a deep lake, Limnol. Oceanogr., 48, 1432-1438, doi:10.4319/lo.2003.48.4.1432, 2003a.

Straile, D., Livingstone, D. M., Weyhenmeyer, G. A., and George, D. G.: The response of freshwater ecosystems to climate variability associated with the North Atlantic Oscillation, in: The North Atlantic Oscillation: Climatic Significance and Environmental Impact, edited by: Hurrell, J. W., Kushnir, Y., Ottersen, G., and Visbeck, M., American Geophysical Union, Washington, D.C., USA, 263-279, 2003b.

Tirok, K. and Gaedke, U.: The effect of irradiance, vertical mixing and temperature on spring phytoplankton dynamics under climate change: long-term observations and model analysis, Oecologia, 150, 625-642, 2007.

Trenberth, K., Jones, P., Ambenje, P., Bojariu, R., Easterling, D., Klein Tank, A., Parker, D., Rahimzadeh, F., Renwick, J., Rusticucci, M., Soden, B., and Zhai, P.: Observations: surface and atmospheric climate change, in: Climate Change 2007: the Physical Science Basis, contribution of Working Group I to the Fourth Assessment Report of the Intergovernmental Panel on Climate Change, edited by: Solomon, S., Qin, D., Manning, M., Chen, Z., Marquis, M., Averyt, K., Tignor, M., and Miller, H., Cambridge University Press, 235-336, 2007.

Ulén, B., Bechmann, M., Fölster, J., Jarvie, H. P., and Tunney, H.: Agriculture as a phosphorus source for eutrophication in the north-west European countries, Norway, Sweden, United Kingdom and Ireland: a review, Soil Use Manage., 23, 5-15, doi:10.1111/j.1475-2743.2007.00115.x, 2007.

Weyhenmeyer, G. A., Adrian, R., Gaedke, U., Livingstone, D. M., and Maberly, S. C.: Response of phytoplankton in European lakes to a change in the North Atlantic Oscillation, Verh. Intern. Verein. Limnol., 28, 1436-1439, 2002.

Whitehead, P. G., Wilby, R. L., Batterbee, R. W., Kernan, M., and Wade, A. J.: A review of the potential impacts of climate change on surface water quality, Hydrolog. Sci. J., 54, 101-123, doi:10.1623/hysj.54.1.101, 2009.

Wilhelm, S. and Adrian, R.: Impact of summer warming on the thermal characteristics of a polymictic lake and consequences for oxygen, nutrients and phytoplankton, Freshwater Biol., 53, 226-237, doi:10.1111/j.1365-2427.2007.01887.x, 2008.

Winder, M. and Hunter, D. A.: Temporal organization of phytoplankton communities linked to physical forcing, Oecologia, 156, 179-192, doi:10.1007/s00442-008-0964-7, 2008.

Zohary, T., Padisák, J., and Naselli-Flores, L.: Phytoplankton in the physical environment: beyond nutrients, at the end, there is some light, Hydrobiologia, 639, 261-269, doi:10.1007/s10750009-0032-2, 2010. 